\title{
"PRINCIPLES OF THE FORMATION OF SOCIOLINGUISTIC COMPETENCE OF STUDENTS OF SECONDARY SCHOOLS (WITH THE UZBEK LANGUAGE OF INSTRUCTION)"
}

\author{
Alimsaidova Sayyora Amideevna \\ Candidate of Pedagogical Sciences, Associate Professor,Department of Russian Language and Literature, Kokand State \\ Pedagogical Institute named after Mukimi, Kokand, Uzbekistan. E-mail: kokand-sayyora@mail.ru
}

\begin{abstract}
:
This article reveals the issues of using the main theoretical provisions of teaching - the principles of the formation of sociolinguistic competence of students of secondary schools (with the Uzbek language of instruction), which determine the basic requirements for the educational process, means and organizational forms of education. On the basis of the study, the article reveals and substantiates the fact that the mastery of the studied principles of teaching by students presupposes the teacher's orientation to certain didactic and methodological patterns in the learning process.
\end{abstract}

Keywords:

principle, sociolinguistics, consciousness, consideration of the native language, communicative-speech orientation, the principle of individualization and differentiation, the principle of speech-behavioral models, the principle of bilingual (bilingual) education. Article Received: 18 October 2020, Revised: 3 November 2020, Accepted: 24 December 2020

\section{INTRODUCTION}

In the scientific literature, there are many definitions of the term "principle" that reveal various aspects of this term. In the methodology of teaching foreign languages, the concept of "principle" has received wide coverage in the works ofmany famous scientists (Bim I.L., Gez N.I., Mirolyubov A.A., Folomkina S.K., Shatilov S.F., Milrud R P., Maksimova I.R., Passov E.I., Rogova G.V., Rabinovich F.M., Sakharova T.E., Safonova V.V., Solovova E.N., Shatilov S.V. ., and etc.). Analyzing the work of these authors, we can say that the principle is usually understood as the main and position of any theory, method, science, taken as the basic rule. Taken together, the principles determine the requirements for the level of mastery of the studied discipline and its individual components. However, theproblem of the principles of teaching a non-native language and their classification continues to be the subject of close attention of scientists and methodologists.

Within the framework of this article, methodological principles are of particular interest, since they form the basis of teaching methods and the theoretical basis of methodology as a science, which proves the need to dwell in detail on the principles of teaching culture. When developing a system of work on the formation of the sociolinguistic competence of students of secondary schools (with the Uzbek language of instruction), we took into account the following principles of communicative, sociocultural and intercultural methods of speech activity in teaching a non-native (Russian) language.

The principle of conscientiousness in teaching a non-native (Russian) language assumes that students understand the content of speech. In this case, you should pay serious attention to analytical work with the language. Let us emphasize that "the knowledge acquired not in a finished form, but in the learning process, in fact reflects the inner qualities of objects and is oriented towards a more conscious mastery of the subject." [4, 190]. The following task is used for this principle: Make up a short story (narration, description, reasoning) on the topic: "Why I love my city (village)", using lexical and grammatical means of expressing cause-and-effect relationships. 


\section{The principle of communicative-speech} orientation (Andriyanova V.I., Bim I.L., Vereshchagina I.N., Passov E.I., Rogova G.V., Shchukin A.N., etc.) presupposes a personalityactivity approach to language learning, the development of specific communication skills in students in connection with the need to express a thought in the target language. In the process of teaching a non-native (Russian) language, teaching communication in an organic relationship with the assimilation of lexical and grammatical means (linguistic means and speech structures) is of particular importance. This principle ensures the active production of speech because it allows freely, in different ways to transform and synthesize the studied language material in various contexts and situations, depending on the specific communicative task $[1,60]$. In addition to the process of educational activity, local history texts of a historical and literary nature, especially those of national importance, which contribute to an increase in the proportion of materials and reflect national realities, help to expand and enrich the content of communication, in addition to the process of educational activities.

In accordance with the principle of communicative-speech orientation, the formation of sociolinguistic competence of students of secondary schools (with the Uzbek language of instruction) is built as a process of real communication, which involves the obligatory conduct of lessons in a non-native (Russian) language, the creation of educationalspeech and speech situations. That is, it isvery important to involve students in the constant oral practice of communication in a non-native (Russian) language. The use of the necessary material in teaching, which has a speech sociolinguistic value, and an increase in the frequency of speech interaction of students in the lesson through various modes of work (individual, pair or group work), as well as repeated practice of language means and speech structures, taking into account changes in the communicative situation, will create favorable conditions for high- quality assimilation and communicationin a nonnative (Russian) language.

To this principle, tasks of the following type are used: Compose a small dialogue using causal constructs:

1. You are interviewing a famous doctor in the city. Ask him why he chose this profession, and how did he become a famous doctor?

2. You explore the history of your native land. Find out why folk artisans are considered valuable?

This principle involves the involvement of students in the development of communication as such, to overcome various difficulties in communication.Their interest in learning a language awakens, which ensures the natural need for multiple repetition of language and speech material, creates a psychological readiness of students for verbal communication, trains them in choosing the desired speech option in educational and speech communication situations; introduces to the norms and values of the country of the target language; fosters independence and cooperation, communication and sociability; develops motivation for learning activities, and, finally, students enjoy the very process of communication and learning.

The content of teaching the Russian language should be aimed at bringing up a harmoniously developed personality, the formation of a cultured and educated person.To this end, we need to take into account the principle of the unity of training and education. The implementation of this principle provides for the appropriate definition of the content, methods and forms of education, the development of a set of tasks that focus on the formation of sociolinguistic competence of students.

\section{MATERIALS AND METHODS}

The principle of situationality and functionality is associated with the studies of A.A. Leontiev, A.A. Alkhazishvili, V.A.Artemov, T.A. Ladyzhenskaya,G.G. Gorodilova, E.I. Passov, G.A. Rubinstein. and other well-known scientists 
who have found that the production of an utterance in real-life situations provides the development of strong oral skills. "The situation as a methodological category is a unit of the organization of the process of teaching foreign language communication" $[6,122]$. Also E. Passov believes that in a situation the functional use of language is an organizing principle, "therefore, speech patterns of certain levels should be organized around speech functions" [7].

The main list of linguistic functions was identified by the scientists of the European Council for Culture [5]. Based on the results of the selection of linguistic functions found in the language, the researchers through the analysis identified the main linguistic categories on which the teaching of communication functions in the secondary school is based:

$>$ Search and communication of factual information (text of a historical and literary nature);

Expression of attitude (language and speech constructions used in the text);

$>$ Problem solving (problem situation on the topic);

$>$ Socialization (dialogue about national realities);

Logical structuring (drawing up dialogues on situations);

Overcoming barriers in communication (communication exercises).

The above categories are used in the formation of the sociolinguistic competence of students of a general education school (with the Uzbek language of instruction) and is implemented in the selection of a number of functional samples at the level of words, phrases and sentences, which are not introduced separately from each other, but only in the context, taking into account the sociolinguistic norms of the Russian language

The principle of taking into account the peculiarities of the native language of students (Azizov A.A., Andriyanova V.I., Bakeeva N.Z., Baskakov E.D., Dzhusupov M.D.,
ZhalalovZh.Zh., Kissen I.A., Lekant A.A., TokhtakhodzhaevaM.Kh., Urumbaev N.A., Shansky N.M., Yusupov U.K., etc.) is based not only on overcoming the interfering influence of the native language, but also in the correct use of skills and knowledge generated in this language. "The transfer of similar speech operations from the native language has a positive effect, first of all, on speech skills (the ability to build coherent statements, conduct a dialogue, extract information, etc.), and not on speech skills" [3, 39]. Sometimes not only translation is required, but translation-interpretation (Why do you think?). This is especially necessary when semantizing vocabulary with a certain background meaning, which are cause-and-effect constructions. For example: Thanks to his intellect, creativity, fair policy, Muhammad Umarkhon (Amiry) went down in history as a wise ruler of Kokand and a world-famous poet. Muhammad Umarhon (Amiriy) o'ziningaql-idroki, ijodi, adolatlisiyosatitufaylitarixgaQo

qonningdonohukmdorivadunyogamashhurshoirbo' libkirdi. In this sentence, the meaning of the dative case with the preposition thanks, denotes the person who is the cause of the action, in the Uzbek language this combination is transmitted by the noun with the word tufayli (for reason, due to) and the word-forming particle ning.

The principle of individualization in the formation of sociolinguistic competence with the help of historical and literary texts provides for taking into account the psychological, mental, age characteristics and abilities of students. According to psychological and linguodidactic studies (Ataeva L.P., BimI.Ya., Dobrynin N.F., Ilyin V.S., Leontiev A.A., Matrinovich T.N., Novikova L.L., etc.), the process of mastering knowledge and skills arouses a cognitive need the more the more students realize their importance, are personally interested in them and successfully "construct" their thinking in the process of mastering the educational material. Teaching a non-native (Russian) language, more than another subject, requires an individual approach. Based on 
the experience of our practical work in school, historical and literary texts provide ample opportunities for the development of individualized tasks of varying degrees of difficulty, due to the level of general and speech development of students, thereby creating the basis for the progressive development of all students.

Speech-thinking activity is also caused by complex tasks such as: make a message about the artists of Kokand known to you (according to the program); retell the content of the film dedicated to the poetess Uvaisi; give a description of the literary character (for example, from the work of Mukimi "Land surveyors"). Such tasks and the training system require the teacher to work aimed at developing students' speech, attracting literary materials, in particular local history texts of a historical and literary nature, which enrich the intellectual and spiritual and moral potential of the student's personality, which in turn develops speech and thinking abilities, helps development observation, thinking and other aspects of the personality of students.

\section{The principle of stylistic differentiation is} associated with the research of Safonova V.V., Shchukin A.N., Leaver BL, Ehrman M., Shekhtman V. and other scholars who have established that the choice of a certain stylistic orientation of the text (in our case, the historical and literary text), intended for reproduction, involves explaining students their choice. This principle can be implemented through the selection of lexical units for each student, through the use of grammatical structures that differ from each other (the more formal the communication environment, the more students' speech is filled with speech constructions, complex sentences (SSP, SPP, BSP), introductory words and linguistic cliches used in the speech of the speaker).

The task. Make sentences using phrases in them: did not say out of delicacy, laughed with joy, turn pale with fear, marry for love, thanks to support, for a good reason, came by accident, just in case.
The task. Insert meaningful conjunctions. The Fergana Valley is called the pearl of our republic ... it resembles an oval dish in shape. Most of it is lowland. ... spring comes here early and summer is hot and dry for a long time, ... the largest and most delicious fruits grow here. Autumn is a wonderful time in the valley. ... trees remain green for a long time, apples, pears, grapes ripen.

Words for references: because, because, because, therefore.

\section{The principle of problematicity in didactics} implies a reflection of "changes in the structure of the content of educational material and a combination of teaching methods based on logical and cognitive contradictions of the learning process and characterizing the ways of implementing these patterns in accordance with the goals of teaching, the development of intellectual abilities of students and their upbringing" [2].

The use of this principle in practice shows that if students are faced with the need to solve educational problems, then in the process of solving them they develop qualities that characterize an individual and creative personality. This need has a pattern: it always manifests itself when all students are involved in the educational process to solve the problem and search for new knowledge.

In our opinion, to implement the principle of problematicity, at the stage of development of speech skills in the formation of sociolinguistic competence of students of a general education school (with the Uzbek language of instruction), it is necessary to use the method of active problemsituational analysis based on learning by solving specific problems - situations (Case Studies), which will ensure that students have a strategy and tactics, determine the productivity of students' statements and will contribute to the development of language and speech activity of students. The result will be not only knowledge, but also competencies that are formed in the process of solving the case. 
The principle of problematicitycan be implemented in the joint activities of the teacher and the trainees to create problem situations when working with Case Study. The teacher needs to bring to the consciousness of the students that there is a problem and the need to solve it, that is, a problem situation is needed. Discussion, formulation, search for ways to solve a problem situation and problem are possible only with active speech interaction of students with each other and with the teacher as with equal speech partners. In the process of solving the problem, the teacher:

$>$ provides assistance to students at all stages of the educational process;

$>$ informs students about the essence of their actions;

$>$ encourages students to become aware of their actions.

\section{RESULT AND DISCUSSION}

This principle is also implemented when solving communication problems.

\section{The principle of speech-behavioral models,} implemented in the formation of sociolinguistic competence, is understood as a line of behavior based on knowledge of cultural values and the ways of their reflection in speech, on knowledge concerning the culture of the target language, on knowledge of a possible clash or interaction of cultures, on motivation to acquire new knowledge , on the ability to use all this knowledge in communication situations, as well as through the new content of the actual speech exercises.

When forming the sociolinguistic competence of students of secondary schools (with the Uzbek language of instruction), the principle of speech-behavioral models can be reflected in the new use of the traditional method of teaching Russian in a foreign language school. This method is associated with teaching communication: the trainees are offered first theory, and then the practical side of mastering the methods of starting and ending a conversation (in addition to greetings and farewells, etiquette phrases in the context of official, neutral and unofficial styles of texts of a historical and literary nature). That is, students master this type of speech behavior, which is aimed at recreating and mastering the speech of the language being studied.

The task. Answer the questions:

1. Tell me, the names of what outstanding personalities who lived and worked in Kokand are inscribed in golden letters in the history of Uzbek literature? (Nadira, Amiri, Uvaisi, Mukimi, Furkat, Zavki, Khamza, U. Nosir, Charkhi, A. Kakhkhar, L. Solovyov, etc.). Why do you think?

2. Why the creativity of the Uzbek poetess of the 17th century. Were the Nodirs interested in Uzbek and Tajik scholars, literary critics and poets, doctors of sciences and academicians? (SadriddinAini, GafurGulyam, Hamid Alimjan, AlimSharafutdinov, VakhidZakhidov, VakhidAbdullaev, Aziz Kayumov, Utkir Rashid, TokhtasinJalilov and others).

3. Why do you think the poet Nadira died?

\section{The principle of the dialogue of cultures.} Recently, the concept of "dialogue of cultures" is often used in scientific literature. The analysis of the literature on the problem of the relationship between cultures (Bakhtin M.M., Bibler V.S., Vygotsky L.S., Kagan M.S., Safonova V.V., etc.) shows that "the dialogue of cultures "Is a philosophy of relations between cultures in modern society. In order for the "dialogue of cultures" to be used as one of the leading goals of communication between people, it is necessary to make this "dialogue of cultures" one of the main goals of education at school.

As one of the leading pedagogical goals of general education, the dialogue of cultures as a process of communication can be achieved through the study of a non-native (Russian) language. In the methodology of teaching languages based on the "dialogue of cultures" [9, 17] is considered:

$>$ the need to analyze cultural material in order to use it in curricula and teaching materials on the Russian language on the principle of expanding 
the range of studied cultures (from ethnic, social subcultures to civilizational strata and their reflection in world culture);

$>$ the formation of such important qualities as tolerance, readiness to communicate in a foreign cultural environment, speech and socio-cultural tact, etc.;

development of students' abilities that contribute to the formation of bilingual (RussianUzbek languages) sociolinguistic competence, including the awareness of each student of himself as a cultural and historical subject, which is a representative and bearer of several types of cultures (ethnic, social, professional, religious, etc.) .) [8];

creating conditions for preparing such situations where speech partners appear before each other as carriers of different nationallinguistic-cultural communities, ready to communicate in different situations, with different representatives (carriers of different statuses and roles) of these communities, in various spheres of communication in formal, neutral and informal communication keys.

When forming the sociolinguistic competence of students of secondary schools (with the Uzbek language of instruction), the principle of the dialogue of cultures allows the most successful way to carry out interpersonal contacts, establish social ties and interactions.

The task. Make a dialogue on the following situation:

1. You are at an exhibition of folk artists at the local museum of local lore. You liked the exhibition very much. What do you want to ask the organizers of the exhibition?

2. What are the similarities and differences between Uzbek ceramics and Russian Gzhel (Gzhel is a folk ceramic art of the Russian people).

3. Tell us about your favorite art form.

Also in the formation of sociolinguistic competence, we highlight the principle of student independence in learning activities to master a non-native (Russian) language, in which we pay special attention to the activities of the student himself in the process of assimilating a non-native (Russian) language, when mental and verbal-cogitative activity is realized in the pleasure of communication among themselves during the educational process.Taking this principle into account is necessary to stimulate independent learning activities of students, which imitate real communication (thematic dialogues), and then independent and active communication in real conditions, when students can consciously evaluate their speech behavior using personal speech experience.

\section{The principle of bilingual (bilingual) education} In the scientific literature, there is still no consensus on the use of the native language in the lessons of a non-native (Russian) language. Some scientists believe (Zelentsov B.P.) that the use of a non-native (Russian) language will lead to the early formation of a foreign language communicative competence. Others (Andriyanova V.I., Byram M., Safonova V.V., Solovova E.N., Sysoev P.V.), call for the reasonable use of the native (Uzbek) language in the lessons of a nonnative (Russian) language.

In this article, we consider the fact that when teaching culture, the native (Uzbek) language is not only allowed, but even mandatory to use. This is explained by the fact that when teaching culture, four facets of the goal of teaching languages are simultaneously realized:

educational goal (acquaintance and the ability to comment on phenomena and facts of co-studied cultures, the formation of knowledge about the peculiarities of the functioning of the Russian language in neighboring countries and in the world; the ability to collect and systematize various types of cultural information);

educational goal (the formation of students' patriotism, morality, awareness of their role and responsibility in the global human processes taking place both in our Republic, and in Russia and the world; aesthetic and spiritual development of the personality of students); 
educational goal (acquisition of knowledge about the culture of the country of the studied (Russian) language, including both high (literature, fine arts, theater, history) and popular culture (clothing, food, use of public transport, pastime of youth, etc.);

developing goal (development of sociocultural and sociolinguistic education of students of secondary schools, allowing them to participate in intercultural communication in a non-native (Russian) language in the social, cultural, educational and professional spheres; teaching the basics of ethics of communication in a non-native (Russian) language when discussing culture and lifestyle of people in co-studied communities).

The task. Make up of two simple sentences complex with a subordinate part of cause and effect.

1. The real adornment of Uzbek women is the fabric - khan-atlas. It is created from natural silk.

2. According to legend, it was created by a poor weaver from Margilan. Margilan is the center for the production of khan-atlas in the republic.

3. Copper-stamped items were created by craftsmen of three specialties. Coppersmiths made molds, casters cast vessels, embossers decorated items with fine chasing and engraving.

4. The art of wood carving is developed in Kokand. Decorative multifaceted tables, walnut stools and plane trees are made here.

5. Fergana is famous for its askiyachi (masters of words). Well-known word masters Mukhiddin Darveshov, Abdulla Akbarov, Mamasiddik Shiryaev and others were born and live on this land.

\section{CONCLUSION}

Lack of opportunity to use the native (Uzbek) language can lead to misunderstanding, misunderstanding, incorrect explanation of the studied facts and cultural realities. Each student, being the subject of the dialogue of cultures, must be able to correctly translate cultural vocabulary into their native language. Highlighting the principle of bilingual (bilingual) education separately, we wanted to significantly expand the scope of using the native language for more effective mastering of culture in order to increase sociolinguistic competence, which in turn activates creativity and positively affects the comprehensive development of the personality of students of secondary schools (with the Uzbek language of instruction).

\section{REFERENCES}

[1] Andriyanova V.I. Improving the teaching of Russian oral speech for Uzbek schoolchildren. - Tashkent: Fan, 1988 .$95 \mathrm{p}$.

[2] VyatutnevM.N.Methodological aspects of a modern textbook of Russian as a foreign language // Russian language abroad.- M., 1988. - No. 3. - S. 71-77.

[3] Krysin L. P. Sociolinguistic aspects of studying the modern Russian language / L. P. Krysin. - M .: Nauka, 1989 .- P. 188.

[4] Makhmutov M.M. The principle of problematicity in teaching // Questions of pedagogy. - 1984. - No. 4. - S. 30-36.

[5] Menac A. Types of interference in the study of the Russian language by native speakers of the Croatian-Serbian language // Methods of teaching the Russian language abroad. - M., Pedagogy, 1981 .- $172 \mathrm{p}$.

[6] Milrud R.P., MaksimovaI.R.Modern conceptual principles of communicative teaching of foreign languages. // Foreign languages at school.- Moscow, 2000. No. 4. - P. 9-15;- No. 5. - S. 17-22.

[7] New pedagogical thinking / Ed. A.V. Petrovsky. - Moscow: Pedagogy, 1989 .$280 \mathrm{p}$.

[8] Common European Framework of Reference for Languages: Study, Teaching, Assessment. - M .: MGLU, 2003 .- 256 p.

[9] Passov E.I. Fundamentals of communicative methods of teaching foreign language communication. - M .: Russian language, 1989 .- 276 p. 
[10] Passov E.I., Tsarkova V.B. The concept of communicative teaching of foreign language culture in secondary school. - M $\therefore$ Education, 1993 .- 127 p.

[11] Safonova V.V. Sociocultural approach to teaching foreign languages. - M .: Higher School, Amscourt International, 1991 .305 p.

[12] Safonova V.V. Cultural studies in the system of modern language education // Foreign languages at school. - 2001. - No. 3. - S. 17-24.

[13] SolovovaE.N."Methods of teaching foreign languages" (Basic course of lectures) Moscow "Education", 2002. $238 \mathrm{p}$.

[14] Dictionary of sociolinguistic terms // Otv. ed .: D. philol. n. V.Yu. Mikhalchenko. M : Russian Academy of Sciences. Institute of Linguistics; Russian Academy of Linguistic Sciences, 2006. URL: http 